\title{
Yellow may: an active campaign to prevent road traffic injury
}

\section{Maio amarelo: um movimento ativo para prevenir lesões no trânsito}

\author{
Gustavo Pereira Fraga, tCBC-SP1; Paulo Roberto Carreiro, tCBC-Mg²; Hamilton Petry de Souza, TCBC-RS3; \\ SANDRO SCARPELINI, TCBC-SP4
}

In 2015 the Journal of the Brazilian College of Surgeons brings, for the fourth consecutive year, edition 4, dedicated to themes of trauma and emergency surgery. With the support of the Brazilian Society of Integrated Assistance to the Traumatized (SBAIT) it is widely disseminated and invites the surgeons and their departments to submit articles, to be evaluated by guest editors in an agile and competent way ${ }^{1}$. The number of submitted articles is increasing annually; in 2012 and 201318 articles were received, in 201419 (with 11 being published) and this year 35 original articles and three review articles have been received, with a total of 15 (39.5\%) being approved for publication. Within this number, readers can read interesting studies about pedestrian accidents, neck, chest, abdomen and extremity trauma, non-operative treatment of penetrating liver trauma, trauma registries, the risks of nocturnal admission of trauma patients and brief interventions for alcoholic trauma victims. In other words, research articles ranging from prevention to specialized treatments.

While we celebrate the increase in the production of trauma surgery articles in Brazil, a subject that brings great concern to all of society is the alarming number of traffic fatalities, as well as the thousands of patients admitted to emergency units every year. In 2010 the United Nations (UN) General Assembly proclaimed the period 2011-2020 as the "Decade of Action for Road Safety"2. Studies by the World Health Organization (WHO) showed that around 1.3 million deaths were caused by traffic events in 178 countries in the year 2009. Brazil appeared in $5^{\text {th }}$ place among those countries with most traffic accidents, surpassed only by India, China, the United States of America (USA) and Russia ${ }^{2}$. In 2011 the federal government launched the "National Pact for the Reduction of Traffic Accidents A Pact for Life", aiming to seek the participation of the executive, legislative and judicial powers, the three levels of government, and civil society in reducing traffic accidents and violence. Between 2001 and 2012, the number of deaths due to traffic accidents in Brazil increased almost 50\%. In 2013 there were 42,266 traffic fatalities in Brazil ${ }^{3}$, which is failing to achieve traffic fatality reduction, as proposed by the UN. In November of 2015, Brasilia will host the UN Road Safety Organization's Second Global Ministerial Conference in order to take stock of the achievements of the "Decade of Action for Road Safety". All health professionals who care for trauma patients need to spread the prevention efforts.

In the area of oncology, prevention campaigns are widespread and have provoked effective participation by the population. One example is "Pink October", which started in the USA in the 1990s, spreading the awareness and importance of the prevention of breast cancer by encouraging the population to participate in various initiatives. This campaign began in Brazil in 2008 with the support of several medical organizations.

In 2014 the "Yellow May" movement was launched in Brazil, in an effort to draw society's attention to the high rate of deaths and injuries which occur in traffic throughout the world ${ }^{4}$. The goal is to put road safety on the agenda and to mobilize society into participating in various education and prevention programs. The movement was launched by the "National Observatory for Road Safety" $(\mathrm{ONSV})^{5}$ and from the beginning, SBAIT has been committed to this cause, so much so that the national launch of Yellow May was held on April 24, 2015, in Campinas, during the election of the new SBAIT board, along with the opening of the two high-profile events "Il Ibero-Afro-American Meeting on Trauma and Emergency Surgery (RIAATCE)" and "Intergastro \& Trauma". The Brazilian Committee of Trauma Leagues (CoBraLT) ${ }^{6}$ is also actively participating along with their students, participating in various prevention programs.

The participation of various organizations is boosting the effect of the "Yellow May" movement, which is an ongoing effort, with monthly thematic events, and which needs the involvement of surgeons and other health professionals. In 2015, the movement has been promoted in 21 countries on five continents, with the support of 600 organizations and companies, achieving over 30,000 'likes' on Facebook and over 200,000 views of the "Yellow May" videos.

SBAIT and The Brazilian College of Surgeons invite you to be part of this movement. Our goal is to enhance the research and teaching within the trauma and emergency

1. Disciplina de Cirurgia do Trauma do Departamento de Cirurgia da Faculdade de Ciências Médicas da Universidade Estadual de Campinas (Unicamp), Campinas, SP, Brasil; 2. Hospital João XXIII, Belo Horizonte, MG, Brasil; 3. Pontifícia Universidade Católica do Rio Grande do Sul (PUC RS), Porto Alegre, RS, Brasil; 4. Faculdade de Medicina de Ribeirão Preto, Universidade de São Paulo (USP), Ribeirão Preto, SP, Brasil. 
surgery field, and working alongside prevention campaigns, we will see a reduction in the aforementioned statistics, a crucial factor in actually calling our country a developed one.

\section{REFERENCES}

1. Fraga GP, Manso JEF, Starling SV. CBC e SBAIT: somando para multiplicar. Rev Col Bras Cir. 2012;39(4):247-8.

2. Woeld Health Organization (WHO). Global Plan for the Decade of Action for Road Safety 2011-2020. The World Health Organization. [acessado em: 01 jul 2015]. Disponível em: http://www.who.int/ roadsafety/publications/global_launch.pdf?ua=1

3. Brasil. Ministério da Saúde. Datasus. Departamento de Informática do Sistema Único de Saúde (TABNET). [acessado em: 01 de julho de 2015]. Disponível em: http://tabnet.datasus.gov.br/cgi/ tabcgi.exe?sim/cnv/ext10uf.def

4. Movimento Maio Amarelo [homepage na Internet]. [acessado em: 01 jul 2015]. Disponível em http://maioamarelo.com.

5. Observatório Nacional de Segurança Viária (ONSV). [homepage na Internet]. [acessado em: 01 jul 2015]. Disponível em: http:// onsv.org.br

6. Comitê Brasileiro das Ligas do Trauma (CoBraLT). [homepage na Internet]. [acessado em: 01 jul 2015]. Disponível em: http:// cobralt.com.br. 